\title{
Ammonium concentration in ice cores: A new proxy for regional temperature reconstruction?
}

\author{
T. Kellerhals, ${ }^{1,2,3,4}$ S. Brütsch, ${ }^{2}$ M. Sigl, ${ }^{1,2}$ S. Knüsel, ${ }^{1,2}$ H. W. Gäggeler, ${ }^{1,2}$ \\ and M. Schwikowski ${ }^{2,3}$ \\ Received 15 June 2009; revised 22 December 2009; accepted 8 March 2010; published 31 August 2010.
}

[1] We present a reconstruction of tropical South American temperature anomalies over the last $\sim 1600$ years. The reconstruction is based on a highly resolved and carefully dated ammonium record from an ice core that was drilled in 1999 on Nevado Illimani in the eastern Bolivian Andes. Concerning the relevant processes governing the observed correlation between ammonium concentrations and temperature anomalies, we discuss anthropogenic emissions, biomass burning, and precipitation changes but clearly favor a temperature-dependent source strength of the vegetation in the Amazon Basin. That given, the reconstruction reveals that Medieval Warm Period- and Little Ice Age-type episodes are distinguishable in tropical South America, a region for which until now only very limited temperature proxy data have been available. For the time period from about 1050 to $1300 \mathrm{AD}$, our reconstruction shows relatively warm conditions that are followed by cooler conditions from the 15 th to the 18th century, when temperatures dropped by up to $0.6^{\circ} \mathrm{C}$ below the 1961-1990 average. The last decades of the past millennium are characterized again by warm temperatures that seem to be unprecedented in the context of the last $\sim 1600$ years.

Citation: Kellerhals, T., S. Brütsch, M. Sigl, S. Knüsel, H. W. Gäggeler, and M. Schwikowski (2010), Ammonium concentration in ice cores: A new proxy for regional temperature reconstruction?, J. Geophys. Res., 115, D16123, doi:10.1029/2009JD012603.

\section{Introduction}

[2] To place recent global warming into a longer-term perspective and to understand the mechanisms and causes of climate change, proxy-derived temperature estimates are needed for time periods prior to instrumental records and regions outside instrumental coverage. The amplitude and spatiotemporal extent of climate fluctuations during past millennia are vividly debated. Although the terms Little Ice Age (LIA) and Medieval Warm Period (MWP) can be used beyond controversy to describe the most recent extensive advances of alpine glaciers in Europe from the 16th to the 19th century and the comparatively warm conditions in Europe from the 10th to the 13th century, their notion for globally synchronous cold and warm periods have been dismissed. Although there is evidence for colder and warmer periods during past millennia also outside the influence of the

\footnotetext{
${ }^{1}$ Department of Chemistry and Biochemistry, University of Bern, Bern, Switzerland.

${ }^{2}$ Laboratory of Radiochemistry and Environmental Chemistry, Paul Scherrer Institute, Villigen, Switzerland.

${ }^{3}$ Oeschger Centre for Climate Change Research, University of Bern, Bern, Switzerland.

${ }^{4}$ Now at Climate and Environmental Physics, Physics Institute, University of Bern, Bern, Switzerland.

Copyright 2010 by the American Geophysical Union. 0148-0227/10/2009JD012603
}

North Atlantic [Jones and Mann, 2004; Mann et al., 2009], their timing, magnitude, and spatial extent are unclear. This is especially true for tropical regions and the Southern Hemisphere $(\mathrm{SH})$, where proxy information is very fragmentary. Stable isotope data from high-elevation ice cores can provide long records and have been interpreted with respect to past temperature variability [Thompson et al., 2003]. However, calibration attempts and modeling studies for South America point to a dominant sensitivity to precipitation, at least on annual and decadal timescales [Hoffmann et al., 2003].

[3] Ammonium $\left(\mathrm{NH}_{4}^{+}\right)$records in midlatitude and lowlatitude ice cores commonly serve as seasonally varying signals to distinguish different seasons and are used, for example, for dating purposes. $\mathrm{NH}_{4}^{+}$archived in ice cores is originally emitted as ammonia $\left(\mathrm{NH}_{3}\right)$ into the atmosphere, where it is rapidly converted to accumulation-mode aerosol compounds such as $\mathrm{NH}_{4} \mathrm{HSO}_{4}$ and $\mathrm{NH}_{4} \mathrm{NO}_{3}$. These species have atmospheric lifetimes of several days and can be transported over relatively long distances when they are not removed by precipitation. While the major part of presentday global $\mathrm{NH}_{3}$ emissions is of anthropogenic origin, natural sources mainly comprise biogenic emissions from soils and vegetation and from the oceans, but their exact contribution to the global budget remains unclear [Bouwman et al., 1997]. We argue that the dominant sources for $\mathrm{NH}_{4}^{+}$in the Illimani ice core are soil and vegetation emissions in the Amazon Basin, while other sources such as the Atlantic Ocean, biomass burning, and anthropogenic contributions are of minor 


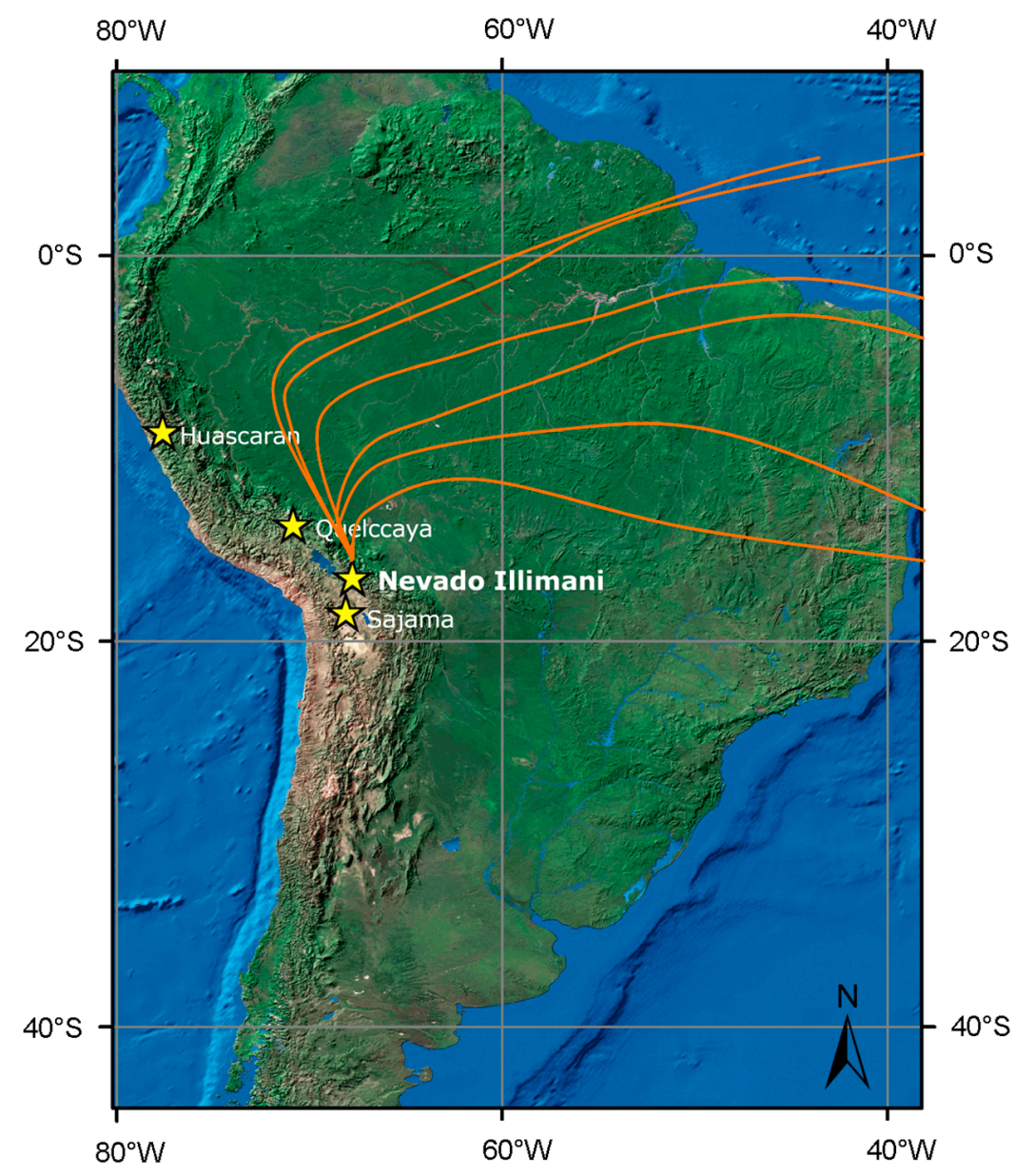

Figure 1. Satellite image of South America and location of Nevado Illimani $\left(16^{\circ} 37^{\prime} \mathrm{S}, 67^{\circ} 46^{\prime} \mathrm{W}\right)$ in the eastern Bolivian Andes. Huascaran, Quelccaya, and Sajama ice core sites are also indicated. Back trajectories (orange) of the air masses arriving in the nearby Zongo valley (adapted from Vimeux et al. [2005]) are shown to illustrate the typical pathways of air masses over the Amazon Basin.

importance for this remote site. Soils contain $\mathrm{NH}_{3}$ from bacterial plant decomposition and release it to the atmosphere when the ambient $\mathrm{NH}_{3}$ concentration drops below the vapor pressure of the soil solution [Langford and Fehsenfeld, 1992]. Gaseous $\mathrm{NH}_{3}$ is also present in substomatal cavities within plant leaves, from where it is emitted if its concentration is higher than the ambient $\mathrm{NH}_{3}$ concentration. Absorption of ambient $\mathrm{NH}_{3}$ into the leaf occurs if the opposite is true. The net flux between atmosphere and vegetation is governed by the "canopy compensation point" (the atmospheric concentration above which plants assimilate and below which they emit $\mathrm{NH}_{3}$ ). This compensation point is strongly temperature-dependent with higher values for higher temperatures [Dentener and Crutzen, 1994]. As long as ambient $\mathrm{NH}_{3}$ concentrations are below the compensation point, $\mathrm{NH}_{3}$ is emitted into the atmosphere. Studies from other remote ice core sites have found significant correlations between $\mathrm{NH}_{4}^{+}$ concentration and temperature for Siberia and the Indian subcontinent for preindustrial time periods [Eichler et al., 2009; Kang et al., 2002].

[4] Here we present a highly resolved $\mathrm{NH}_{4}^{+}$record from a high-altitude ice core from Nevado Illimani, Bolivia, and discuss it as a novel proxy for tropical South American temperatures over the last $\sim 1600$ years.

\section{Ice Core Material and Methods}

[5] In 1999, two parallel ice cores were retrieved from Nevado Illimani $\left(16^{\circ} 37^{\prime} \mathrm{S}, 67^{\circ} 46^{\prime} \mathrm{W}, 6300 \mathrm{~m}\right)$ in a joint operation of the French Institut de Recherche pour le Développement (IRD) and the Swiss Paul Scherrer Institute (PSI). Both ice cores reached bedrock at depths of 111.5 and $113.2 \mathrm{~m}$ water equivalent (weq), respectively. Nevado Illimani is located in the eastern Bolivian Andes at the northeastern margin of the Bolivian Altiplano (Figure 1).

[6] Borehole temperatures were $-7^{\circ} \mathrm{C}$ at $10 \mathrm{~m}$ depth, $-8.9^{\circ} \mathrm{C}$ at $65 \mathrm{~m}$, and $-8.4^{\circ} \mathrm{C}$ near bedrock. These low temperatures and the very few melt features in the firn part indicated well-preserved ion records that are not affected by meltwater percolation. The annual mean net accumulation of $0.58 \mathrm{~m}$ weq [Knüsel et al., 2003] allowed for highly resolved records. Postdepositional effects were investigated and, despite a considerable daily sublimation rate of -0.7 to $-1.2 \mathrm{~mm}$ weq during austral winter [Wagnon et al., 2003], 


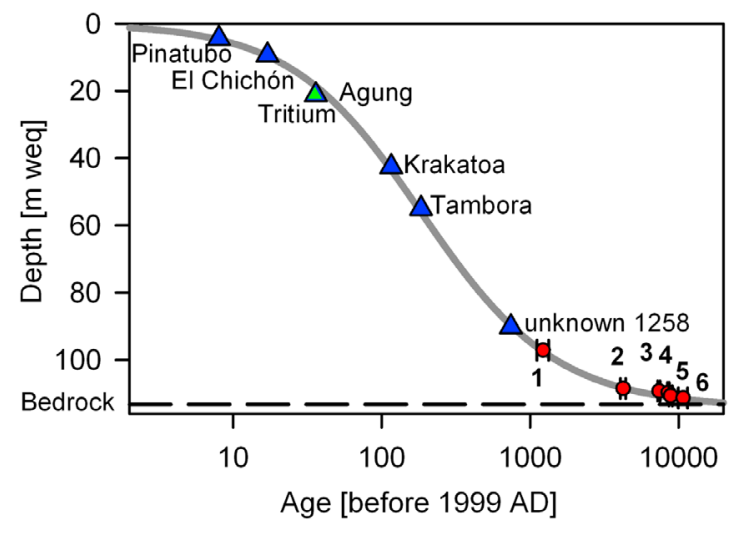

Figure 2. Age-depth relationship for the Illimani ice core on a logarithmic age scale. Blue triangles mark six volcanic time horizons (Pinatubo, 1991; El Chichón, 1982; Agung, 1963; Krakatoa, 1883; Tambora, 1815; and "unknown," 1258); the green diamond is the tritium horizon assigned to $1964 \mathrm{AD}$; the numbered red circles denote six calibrated ${ }^{14} \mathrm{C}$ ages ( $\sigma$ ranges, partly hidden under the circles): 1 (1060-1280 BP), 2 (4000-4350 BP), 3 (7180-7440 BP), 4 (8350-8580 BP), 5 (8540-9010 BP), 6 (9930-11,400 BP). Bedrock at a depth of $113.2 \mathrm{~m}$ weq is indicated by the dashed horizontal line.

the effect on ionic concentrations was weak in comparison to seasonal variations [Bonnaveira, 2004]. There are not many indications that photochemical postdepositional processes alter the signature of the $\mathrm{NH}_{4}^{+}$record, especially at sites with relatively large accumulation rates, and $\mathrm{NH}_{4}^{+}$has been shown to be conservative in the surface snow layer in a field study [Baltensperger et al., 1993].

[7] The moisture leading to precipitation on the Bolivian Altiplano and Nevado Illimani originates from the Amazon Basin and ultimately from the Atlantic [Vimeux et al., 2005], as depicted by typical back trajectories of air masses in the region of the Illimani in Figure 1. The annual cycle of wet summer and dry winter conditions is caused by the seasonal expansion of the equatorial easterlies in the upper troposphere [Garreaud et al., 2003]. The austral summer (December, January, February) rainfall fraction on the eastern Altiplano is 50-60\% [Garreaud et al., 2003], whereas dry conditions usually prevail during the austral winter (June, July, August) associated with enhanced westerly flows restricting moisture transport to the eastern Andes [Vuille, 1999]. Nevado Illimani also gets some precipitation during the dry season through convective circulation originating over the Amazon Basin [Garreaud et al., 2003]. Thus, the ice integrates climatic and atmospheric information over a substantial portion of the year and may serve, although certainly biased toward the wet season, as a suitable archive for annual conditions.

[8] The timescale for the Illimani core was derived using a multiparameter approach including annual layer counting (ALC), known reference horizons from nuclear bomb testing with a tritium maximum attributed to $1964 \mathrm{AD}$, and data from volcanic eruptions that deposited significant amounts of sulfate on the glacier [Knüsel et al., 2003]. For this study, the Illimani timescale was revised and extended to the lowermost part of the core by additional ${ }^{14} \mathrm{C}$ dating. The very strong signals in excess sulfate and fluoride observed at $90.2 \mathrm{~m}$ weq led to the reassignment of the "unknown 1258" volcanic eruption horizon, which was previously assigned to an electrical conductivity measurement peak at $99.9 \mathrm{~m}$ weq. The lowermost part of the core was dated by applying a novel radiocarbon method requiring only microgram levels of carbonaceous particles in ice [Jenk et al., 2007; Sigl et al., 2009]. Six calibrated ages were determined from 97.1 to $111.3 \mathrm{~m}$ weq depth, which is $1.9 \mathrm{~m}$ weq above bedrock. A two-parameter model [Thompson et al., 1990] was fitted to the following time markers to obtain a continuous depthage relationship: volcanic eruptions of Pinatubo (1991), El Chichón (1982), Agung (1963), Krakatoa (1883), Tambora (1815), "unknown" (1258), and calibrated ${ }^{14} \mathrm{C}$ ages ( $1 \sigma$ errors) of 1060-1280 years BP, 4000-4350 BP, 7180-7440 BP, 8350-8580 BP, 8540-9010 BP, and 9930-11,400 BP (Figure 2). The error of the ALC (until 1800 AD) is estimated to \pm 5 years between volcanic horizons and to \pm 2 years in the vicinity of volcanic time markers. The errors associated with the dating model are estimated to \pm 20 years from 1800 to $1250 \mathrm{AD}$ and to \pm 110 years at the youngest ${ }^{14} \mathrm{C}$ date.

[9] Major ion concentrations were determined with ion chromatography to a depth of $101.6 \mathrm{~m}$ weq, applying a continuous sampling with a gradually increasing resolution from 6 to $2.5 \mathrm{~cm}$. Decontamination of the samples was performed using established techniques [Eichler et al., 2000]. Here we focus on the $\mathrm{NH}_{4}^{+}$record that covers the time period from $\sim 350$ to $1998 \mathrm{AD}$.

\section{Calibration and Validation of the Proxy Record}

[10] Because there are no long time series of instrumental station data available for the region of interest, we used the Amazon Basin subset (coverage: $82^{\circ} \mathrm{W}$ to $34^{\circ} \mathrm{W}, 12^{\circ} \mathrm{N}$ to $20^{\circ} \mathrm{S}$; domain: land; as depicted in Figure 9.12 in chapter 9 of the IPCC 2007 report; data extending back to 1905 AD in sufficient quality) of the gridded HadCRUT3 temperature data set [Brohan et al., 2006] for calibration and validation. We chose a gridded data set because it includes all available instrumental data from that region, but rigorously homogenized.

[11] The $\mathrm{NH}_{4}^{+}$data were averaged to yearly values where the temporal resolution was better than 1 year (until $\sim 1100$ AD). For the data from 1998 to 1800 AD, year boundaries were assigned to wet season minima, ensuring that the entire peak was within a given year (JanuaryDecember). Interpolation to yearly values was applied where the resolution dropped to $2-3$ years (from $\sim 1100$ to 350 AD). The yearly averaged $\mathrm{NH}_{4}^{+}$concentrations from 1998 to 1905 AD were split into two series of equal length for calibration (1998-1952) and split-period validation (1951$1905)$ to assess the quality of the reconstruction. Calibration and validation series were highly correlated on an annual basis with the Amazon Basin anomalies $(r=0.78$ and $r=$ 0.80 , respectively; $p<0.001, n=47$; Figure 3 ). The $\mathrm{NH}_{4}^{+}$ concentrations from the calibration period were linearly regressed to the gridded temperature anomalies, and with the obtained regression parameters the reconstructed temperature anomalies for the calibration and validation period were calculated (Figure 4). The reduction of error of 0.52 


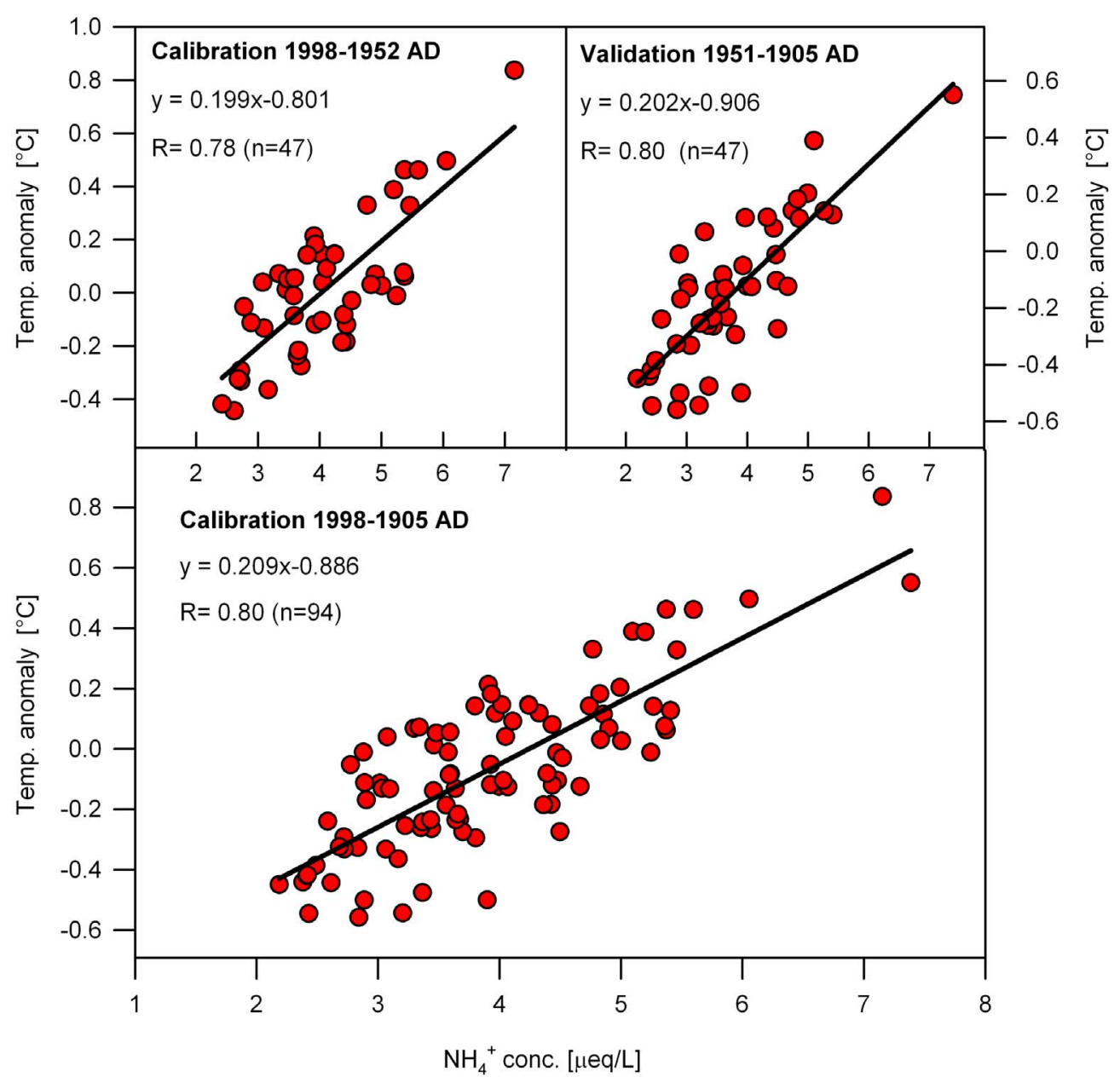

Figure 3. Correlations and regression parameters between the annually averaged $\mathrm{NH}_{4}^{+}$concentrations in the ice core and the Amazon Basin temperature anomalies (deviations from the 1961-1990 average) during the split-calibration period (1952-1998 AD), the validation period (1905-1951 AD), and the full calibration period (1905-1998 AD). If the data point with the highest ammonium concentration during the validation period is considered an outlier, the regression and correlation coefficients for the validation period change only marginally to $y=0.207 x-0.921(R=0.76, n=46)$.

and the coefficient of efficiency of 0.56 confirmed the skill of the reconstruction [Cook et al., 1994]. The reconstruction accurately captures the pronounced warming until 1940 and the temperature decrease toward a local minimum around 1950. It furthermore shows only moderate warming until 1975 and the subsequent strong temperature increase that is evident in the gridded temperature data.

[12] To cover the full range of variability, the whole period (1998 to 1905 AD) was included in the final calibration. However, the model parameters essentially remained the same, indicating a stable relationship between Illimani ice core $\mathrm{NH}_{4}^{+}$concentrations and temperature anomalies (Figure 3).

[13] It is important to discuss the issue whether oceanic or anthropogenic emissions of $\mathrm{NH}_{3}$, or biomass burning, could be responsible for the $\mathrm{NH}_{4}^{+}$variations in the ice core record.

[14] First of all, it is noteworthy that the good correlation between $\mathrm{NH}_{4}^{+}$and temperature anomalies is not caused by a common underlying trend in the two time series, because the correlation of the detrended series is almost as good $(r=0.77$ for the detrended versus 0.80 for the original data). It is therefore very unlikely that year-to-year variations in, for example, anthropogenic emissions or biomass burning could lead by chance to such a correlation.

[15] It seems also unlikely that the Atlantic Ocean is the source for the $\mathrm{NH}_{3}$ which is then, after conversion to $\mathrm{NH}_{4}^{+}$, transported to the Illimani, because it will be scavenged before reaching the ice core site. Anthropogenic sources of $\mathrm{NH}_{3}$ are mainly fertilizers and domestic animals and are estimated to about 3.5 Tg N per year over South America versus $0.7 \mathrm{Tg} \mathrm{N}$ per year for vegetation [Dentener and Crutzen, 1994]. However, the geographical distribution of these sources is such that the regions of the Amazon Basin, where the air masses eventually reaching the Illimani are passing by (see Figure 1), are negligible sources for $\mathrm{NH}_{3}$ from domestic animals and synthetic fertilizers (see plate 1 in the work of Bouwman et al. [1997]).

[16] Although not a direct tracer for anthropogenic agricultural activities, the anthropogenic sulfate record (exsulfate, 


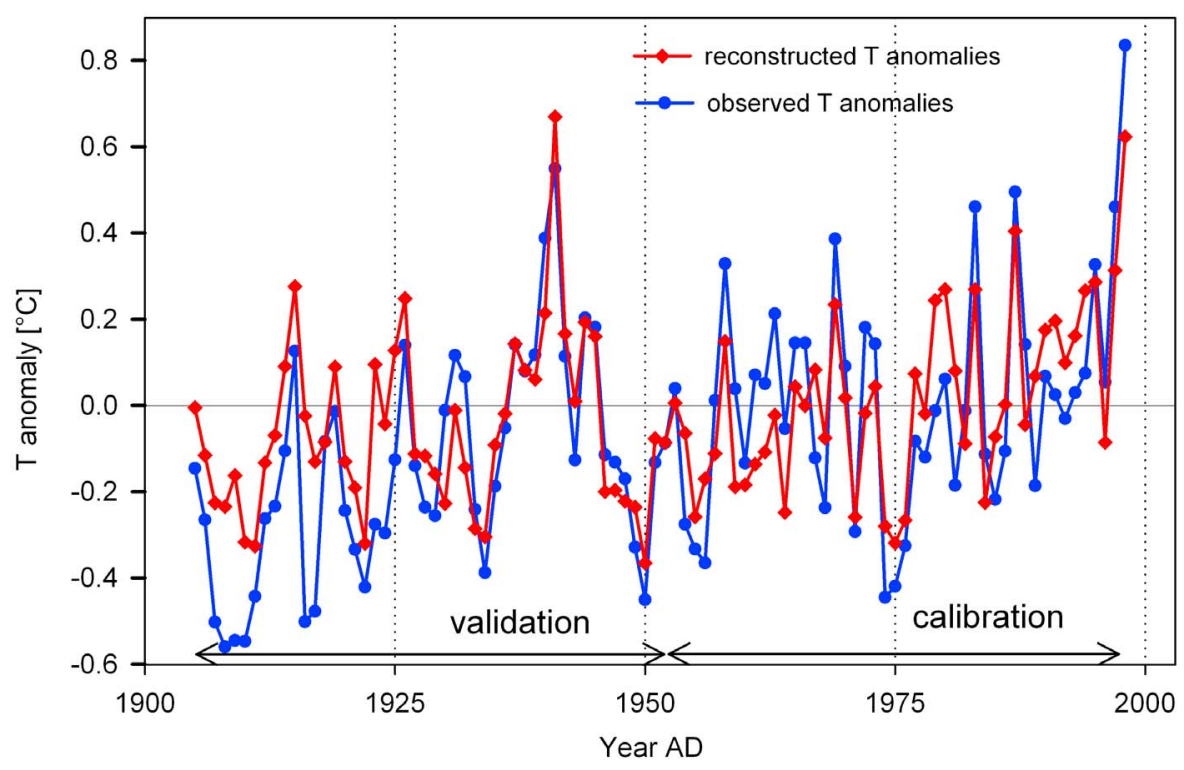

Figure 4. Tropical South American temperature anomalies were reconstructed (red diamonds) from annually averaged $\mathrm{NH}_{4}^{+}$concentrations for the calibration and validation period. The anomalies were obtained via linear regression of the Illimani $\mathrm{NH}_{4}^{+}$concentrations to observed temperature anomalies. The observed Amazon Basin temperature anomalies from the HadCRUT3 data set [Brohan et al., 2006] are shown for comparison (blue circles, normalized to the 1961-1990 average).

calculated to $\mathrm{exSO}_{4}^{2-}=\mathrm{SO}_{4}^{2-}-\mathrm{Ca}^{2+}$; volcanic eruptions excluded) is shown in Figure 5 to illustrate that the anthropogenic fingerprint in the Illimani ice core did not show a significant increase over the 20th century.

[17] $\mathrm{NH}_{4}^{+}$was also used as a tracer for biomass burning in previous ice core studies [Savarino and Legrand, 1998] However, the $\mathrm{NH}_{4}^{+} / \mathrm{K}^{+}$molar ratio of $\sim 14$ in the Illimani core is much higher than the one of $\sim 3$ found in haze layers originating from biomass burning over Amazonia [Talbot et al., 1988]. Concordantly, Talbot et al. [1988] concluded that the magnitude of biomass burning is not yet of a scale

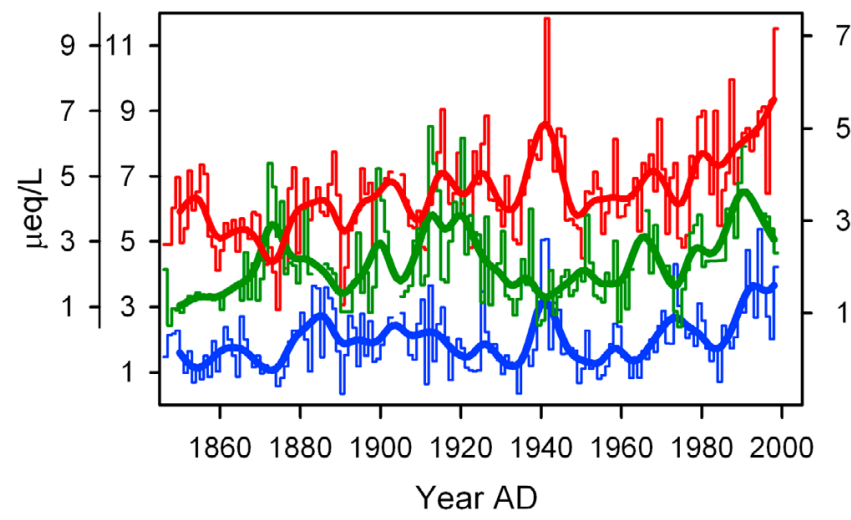

Figure 5. Annually averaged (thin lines) and smoothed with a 21-point binomial filter (bold curves) records for excess sulfate as a tracer for anthropogenic emissions (green, left-hand scale), calcium as a dust tracer (blue, left-hand scale), and ammonium as a proxy for temperature (red, right-hand scale) for the time period 1850-1998 AD. to significantly influence the chemistry of the Amazonian atmospheric aerosol. To further explore whether $\mathrm{NH}_{4}^{+}$is related to biomass burning, a principal component analysis (PCA) was performed on the nine major ions in the time period $\sim 350$ to 1952 to investigate the main sources of the chemical species (Table 1). The first three PCs explained more than $85 \%$ of the data variance. This analysis showed that $\mathrm{NH}_{4}^{+}$was in the first PC (dry season signal) and second PC (biogenic emissions) but not in the third PC, where the biomass burning tracers of $\mathrm{K}^{+}$and $\mathrm{NO}_{3}^{-}$were grouped. $\mathrm{A}$ very similar conclusion was recently drawn from a Belukha ice core recording biogenic emissions from Siberian boreal forests [Eichler et al., 2009].

Table 1. Loadings of the PCA on the 2-Year Means of the Nine Major Ions and the Variance Explained by Each Component for the Time Period $\sim 350-1950 \mathrm{AD}^{\mathrm{a}}$

\begin{tabular}{|c|c|c|c|}
\hline & PC1 & PC2 & PC3 \\
\hline $\mathrm{Ca}^{2+}$ & -0.93 & 0.08 & -0.03 \\
\hline $\mathrm{Mg}^{2+}$ & -0.92 & -0.06 & -0.13 \\
\hline $\mathrm{Na}^{+}$ & -0.90 & -0.01 & 0.04 \\
\hline $\mathrm{Cl}^{-}$ & -0.89 & -0.32 & -0.13 \\
\hline $\mathrm{SO}_{4}^{2-}$ & -0.81 & -0.34 & -0.38 \\
\hline $\mathrm{NH}_{4}^{+}$ & -0.82 & 0.37 & -0.09 \\
\hline $\mathrm{HCOO}^{-}$ & -0.46 & 0.85 & -0.09 \\
\hline $\mathrm{K}^{+}$ & -0.76 & 0.06 & 0.50 \\
\hline $\mathrm{NO}_{3}^{-}$ & -0.71 & -0.28 & 0.37 \\
\hline \multirow{2}{*}{$\begin{array}{l}\text { Variance } \\
\quad \text { explained (\%) }\end{array}$} & 66 & 13 & 6.5 \\
\hline & $\begin{array}{l}\text { Dry season } \\
\text { signal }\end{array}$ & $\begin{array}{l}\text { Biogenic } \\
\text { emissions }\end{array}$ & $\begin{array}{l}\text { Biomass } \\
\text { burning }\end{array}$ \\
\hline
\end{tabular}

\footnotetext{
${ }^{a}$ Species exhibiting the highest loadings in the three PCs are in bold.
} 


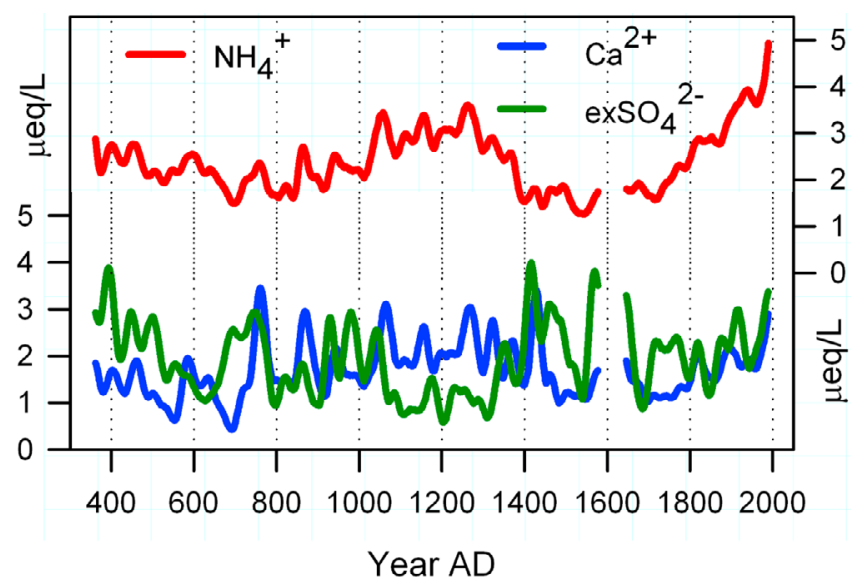

Figure 6. Records (smoothed with a 39-year Gaussian filter) for excess sulfate (green, left-hand scale), calcium (blue, left-hand scale), and ammonium (red, right-hand scale) for the time period 350-1998 AD.

[18] Changes in precipitation over the 20th century are as well unlikely to have induced the $\mathrm{NH}_{4}^{+}$increase as neither the reconstructed accumulation rate nor the $\mathrm{Ca}^{2+}$ concentrations (a proxy for local dust) showed a 20th-century drying trend (Figure 5). In addition, observational data from 42 stations in the tropical Andes revealed no clear trend in regional precipitation; if anything, rather an increase was observed on the eastern slopes of the Andes and in the lowlands to the east [Vuille et al., 2008]. A recent study comparing observed and modeled changes in land precipitation during the 20th century found a moistening in the $\mathrm{SH}$ subtropics and deep tropics [Zhang et al., 2007].

\section{Reconstruction of South American Tropical Temperatures}

[19] Since the dust record in the Illimani ice core is anticorrelated with precipitation [Knüsel et al., 2005], we make use of the $\mathrm{Ca}^{2+}$ record (as a dust tracer) to show that there is no pronounced long-term increase or decrease in mean dust concentration that would imply dramatic changes in the precipitation pattern over the last $\sim 1600$ years (Figure 6). Because anthropogenic $\mathrm{NH}_{4}^{+}$emissions are negligible for the preindustrial time period and because the PCA strongly points to a non-biomass-burning $\mathrm{NH}_{4}^{+}$source, we assume that gaseous $\mathrm{NH}_{3}$ emissions of the vegetation are the major contribution. If so, estimates of the tropical temperature anomalies for the last $\sim 1600$ years can be generated (Figure 7).

[20] The most striking features in the reconstruction are the warm temperatures from $\sim 1050$ to $\sim 1300$ AD compared to the preceding and following centuries, the persistent cooler temperatures from $\sim 1400$ to $\sim 1800 \mathrm{AD}$, and the subsequent rise to warmer temperatures which eventually seem to exceed in the last decades of the 20th century the range of past variation. While the onset of the warm period around $1050 \mathrm{AD}$ is almost consistent within the dating error $( \pm 60$ years at 1000 AD) with the perception of a Northern Hemisphere (NH) MWP from 950 to $1100 \mathrm{AD}$, it is remarkable to note that it seems to have lasted about 200 years longer in the tropics. Owing to the presence of the unknown 1258 volcanic horizon, the end of the warm period can be dated more precisely to $\sim 1300 \mathrm{AD}$. At that time a rather sharp temperature decrease sets in and leads to cooler temperatures already in the beginning of the 15 th century.

[21] A further prominent characteristic is the sustained warming trend that started $\sim 1720 \mathrm{AD}$ and continues until the end of the record. The beginning of the temperature increase is coeval with the end of the Maunder minimum of observed sunspot numbers around 1715 AD. Contrary to many NH reconstructions [Jansen et al., 2007], no distinct cooling interval is evident for the period 1800-1850 AD but rather a stagnation of temperatures and, from this perspective, the LIA in the tropics appears to have ended 50-100 years earlier than in the NH. The temperature difference of $\sim 0.6^{\circ} \mathrm{C}$ between the coldest interval and the 1961-1990 average is smaller than in high latitudes, as it is expected for the tropics.

[22] The warming during the last three decades is not only present in the gridded data; there is also more regional evidence. A compilation of 279 station records shows that temperature in the tropical Andes has increased by approxi-

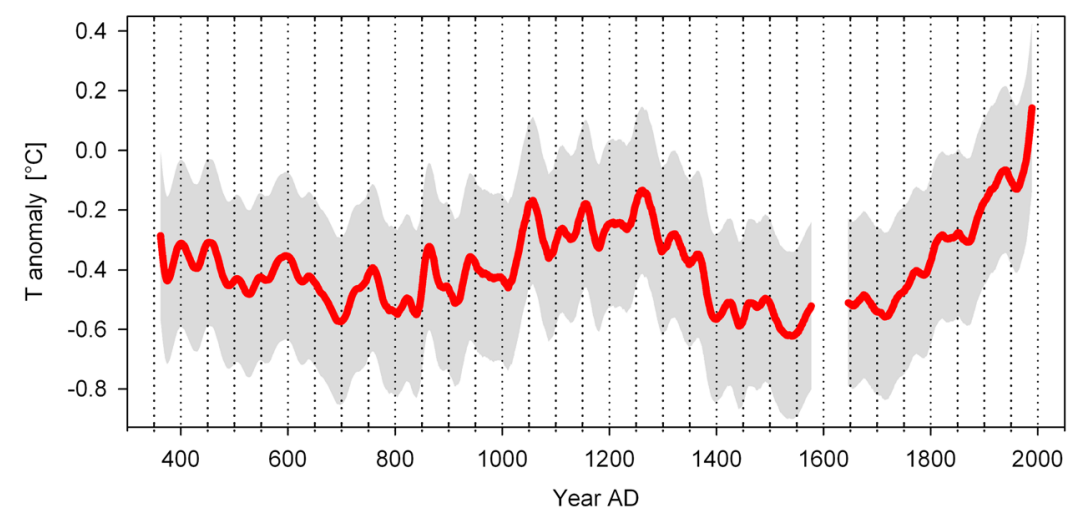

Figure 7. Reconstructed tropical South American temperature anomalies (normalized to the 1961-1990 AD average) for the last $\sim 1600$ years (red curve, smoothed with a 39-year Gaussian filter). The shaded region envelops the $\pm 2 \sigma$ uncertainty as derived from the validation period. Poor core quality precluded any chemical analysis for the time interval between 1580 and $1640 \mathrm{AD}$. 
mately $0.1^{\circ} \mathrm{C} / \mathrm{decade}$ between 1939 and 2006 [Vuille et al., 2008]. Furthermore, glacier retreat in the tropical Andes has accelerated over the last decades as exemplified by the Chacaltaya glacier in Bolivia, which lost $93 \%$ of its volume between 1940 and 1998 [Francou et al., 2003].

[23] On interannual timescales, tropical South American ice core stable isotope records are assumed to be controlled mainly by precipitation [Vimeux et al., 2005]. Accordingly, the 20th-century Illimani $\delta$ Deuterium $(\delta \mathrm{D})$ record [Hoffmann et al., 2003] does not reflect the recent temperature increase, and the correlation between the Illimani $\mathrm{NH}_{4}^{+}$and $\delta \mathrm{D}$ records is only weak $(R=0.30 ; 1905-1998 \mathrm{AD})$. Also on longer timescales, our temperature proxy and available $\delta^{18} \mathrm{O}$ records show different temporal evolutions. On Huascaran, $\delta^{18} \mathrm{O}$ values reached a maximum around $1800 \mathrm{AD}$, remained high during the 19th century, and even slightly declined in the 20th century [Thompson et al., 2006], indicating that temperature was not the dominating control. The Sajama $\delta^{18} \mathrm{O}$ record exhibits only little centennial scale variations over the last 1000 years and likely contains a local signal that varies with water levels in nearby lakes [Thompson et al., 2003]. Only the Quelccaya $\delta^{18} \mathrm{O}$ record (if interpreted as temperature) captures the 20th-century warming and indicates LIA conditions from $\sim 1500$ to $1900 \mathrm{AD}$ [Thompson et al., 2006].

[24] The effect of hydroclimatic changes on the tropical Andes remains inconclusive. Recent studies on Medieval hydroclimate favor a persistent La Niña-like state of the tropical Pacific to explain droughts in western North America and wet conditions in northern South America [Mann et al., 2009; Seager et al., 2007]. Although La Niña would tend to increase precipitation over the tropical Andes [Francou et al., 2003], the Illimani dust record (Figure 7) does not show decreased concentrations that would reflect higher precipitation during this period, arguing against a direct impact of La Niña. We therefore argue that the elevated $\mathrm{NH}_{4}^{+}$ concentrations during the MWP are primarily controlled by temperature.

\section{Conclusions}

[25] $\mathrm{NH}_{4}^{+}$in the Illimani core is assumed to originate mainly from the tropical vegetation in the Amazon Basin and to be transported to the Illimani by easterlies. Warmer tropical temperatures are thought to influence the source strength and therefore to result in higher concentrations of $\mathrm{NH}_{4}^{+}$in the precipitation deposited on the glacier. Using these $\mathrm{NH}_{4}^{+}$concentrations as a temperature proxy, we reconstructed tropical South American temperatures over the last $\sim 1600$ years. Relatively warm temperatures during the first centuries of the past millennium and subsequent cold conditions from the 15th to the 18th century suggest that the MWP and the LIA are not confined to high northern latitudes and also have a tropical signature.

[26] Acknowledgments. The Illimani ice core drilling was a joint project funded by the Institut de Recherche pour le Développement (IRD, France) and the Paul Scherrer Institute (PSI, Switzerland). We are grateful for the excellent work of the drilling expedition, especially Bernard Francou, Robert Gallaire, Patrick Ginot, Bernhard Pouyaud, Ulrich Schotterer, Felix Stampfli, and Benjamin Zweifel. We thank Elisabeth Dietze for preparing the satellite image and Matthias Ruff for ${ }^{14} \mathrm{C}$ analysis.

\section{References}

Baltensperger, U., et al. (1993), Transfer of atmospheric constituents into an Alpine snow field, Atmos. Environ., 27A(12), 1881-1890.

Bonnaveira, H. (2004), Etude des phénomènes de dépôt et post-dépôt de la neige andine sur un site tropical d'altitude, Illimani, Bolivie, Ph.D. thesis, Univ. Joseph Fourier, Grenoble, France.

Bouwman, A. F., et al. (1997), A global high-resolution emission inventory for ammonia, Global Biogeochem. Cycles, 11(4), 561-587.

Brohan, P., et al. (2006), Uncertainty estimates in regional and global observed temperature changes: A new data set from 1850, J. Geophys. Res., 111, D12106, doi:10.1029/2005JD006548.

Cook, E. R., et al. (1994), Spatial regression methods in dendroclimatologyA review and comparison of 2 techniques, Int. J. Climatol., 14(4), $379-402$.

Dentener, F. J., and P. J. Crutzen (1994), A 3-dimensional model of the global ammonia cycle, J. Atmos. Chem., 19(4), 331-369.

Eichler, A., et al. (2000), Glaciochemical dating of an ice core from upper Grenzgletscher (4200 m a.s.1.), J. Glaciol., 46(154), 507-515.

Eichler, A., S. Brütsch, S. Olivier, T. Papina, and M. Schwikowski (2009), A 750 year ice core record of past biogenic emissions from Siberian boreal forests, Geophys. Res. Lett., 36, L18813, doi:10.1029/2009GL038807.

Francou, B., M. Vuille, P. Wagnon, J. Mendoza, and J. Sicart (2003), Tropical climate change recorded by a glacier in the central Andes during the last decades of the twentieth century: Chacaltaya, Bolivia, $16^{\circ} \mathrm{S}$, J. Geophys. Res., 108(D5), 4154, doi:10.1029/2002JD002959.

Garreaud, R. D., et al. (2003), The climate of the Altiplano: Observed current conditions and mechanisms of past changes, Palaeogeogr. Palaeoclimatol. Palaeoecol., 194(1-3), 5-22.

Hoffmann, G., et al. (2003), Coherent isotope history of Andean ice cores over the last century, Geophys. Res. Lett., 30(4), 1179, doi:10.1029/ 2002 GL014870.

Jansen, E., et al. (2007), Palaeoclimate, in Climate Change 2007: The Physical Science Basis. Contribution of Working Group I to the Fourth Assessment Report of the Intergovernmental Panel on Climate Change, edited by S. Solomon et al., pp. 466-474, Cambridge Univ. Press, Cambridge, U. K.

Jenk, T. M., et al. (2007), Microgram level radiocarbon $\left({ }^{14} \mathrm{C}\right)$ determination on carbonaceous particles in ice, Nucl. Instrum. Methods Phys. Res. Sect. B, 259(1), 518-525.

Jones, P. D., and M. E. Mann (2004), Climate over past millennia, Rev. Geophys., 42, RG2002, doi:10.1029/2003RG000143.

Kang, S. C., P. A. Mayewski, D. Qin, Y. Yan, D. Zhang, S. Hou, and J. Ren, (2002), Twentieth century increase of atmospheric ammonia recorded in Mount Everest ice core, J. Geophys. Res., 107(D20), 4595, doi:10.1029/ 2001JD001413.

Knüsel, S., P. Ginot, U. Schotterer, M. Schwikowski, H. W. Gäggeler, B. Francou, J. R. Petit, J. C. Simões, and J. D. Taupin (2003), Dating of two nearby ice cores from the Illimani, Bolivia, J. Geophys. Res., 108(D6), 4181, doi:10.1029/2001JD002028.

Knüsel, S., S. Brütsch, K. A. Henderson, A. S. Palmer, and M. Schwikowski (2005), ENSO signals of the twentieth century in an ice core from Nevado Illimani, Bolivia, J. Geophys. Res., 110(D1), D01102, doi:10.1029/ 2004JD005420.

Langford, A. O., and F. C. Fehsenfeld (1992), Natural vegetation as a source or sink for atmospheric ammonia-A case-study, Science, 255(5044), 581-583.

Mann, M. E., et al. (2009), Global signatures and dynamical origins of the Little Ice Age and Medieval climate anomaly, Science, 326(5957), 1256-1260.

Savarino, J., and M. Legrand (1998), High northern latitude forest fires and vegetation emissions over the last millennium inferred from the chemistry of a central Greenland ice core, J. Geophys. Res., 103(D7), 8267-8279.

Seager, R., et al. (2007), Blueprints for Medieval hydroclimate, Quat. Sci. Rev., 26(19-21), 2322-2336.

Sigl, M., et al. (2009), Towards radiocarbon dating of ice cores, J. Glaciol., 55(194), 985-996.

Talbot, R. W., M. Andreae, T. Andreae, and R. Harriss (1988), Regional aerosol chemistry of the Amazon Basin during the dry season, J. Geophys. Res., 93(D2), 1499-1508.

Thompson, L. G., et al. (1990), Glacial stage ice-core records from the subtropical Dunde Ice Cap, China, Ann. Glaciol., 14, 288-297.

Thompson, L. G., et al. (2003), Tropical glacier and ice core evidence of climate change on annual to millennial time scales, Clim. Change, 59(1-2), $137-155$.

Thompson, L. G., et al. (2006), Abrupt tropical climate change: Past and present, Proc. Natl. Acad. Sci. U. S. A., 103(28), 10536-10543.

Vimeux, F., R. Gallaire, S. Bony, G. Hoffmann, and J. Chiang (2005), What are the climate controls on delta $\mathrm{D}$ in precipitation in the Zongo 
Valley (Bolivia)? Implications for the Illimani ice core interpretation, Earth Planet. Sci. Lett., 240(2), 205-220.

Vuille, M. (1999), Atmospheric circulation over the Bolivian Altiplano during dry and wet periods and extreme phases of the Southern Oscillation, Int. J. Climatol., 19(14), 1579-1600.

Vuille, M., et al. (2008), Climate change and tropical Andean glaciers: Past, present and future, Earth Sci. Rev., 89(3-4), 79-96.

Wagnon, P., J.-E. Sicart, E. Berthier, and J.-P. Chazarin (2003), Wintertime high-altitude surface energy balance of a Bolivian glacier, Illimani, $6340 \mathrm{~m}$ above sea level, J. Geophys. Res., 108(D6), 4177, doi:10.1029/ 2002JD002088.
Zhang, X., et al. (2007), Detection of human influence on twentiethcentury precipitation trends, Nature, 448(7152), 461-465.

S. Brütsch and M. Schwikowski, Laboratory of Radiochemistry and Environmental Chemistry, Paul Scherrer Institute, CH-5232 Villigen PSI, Switzerland.

H. W. Gäggeler, S. Knüsel, and M. Sigl, Department of Chemistry and Biochemistry, University of Bern, Hochschulstrasse 4, CH-3012 Bern, Switzerland.

T. Kellerhals, Climate and Environmental Physics, Physics Institute, University of Bern, Sidlerstrasse 5, CH-3012 Bern, Switzerland. (kellerhals@climate.unibe.ch) 